\title{
Convention on the Rights of the Child and Adultism: How to Deconstruct a Myth?
}

\author{
Jelena Vranješević, Faculty of Philosophy, University of Belgrade
}

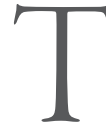

he image of the child in the Convention on the Rights of the Child (CRC) (1989) is represented by three "Ps": protection, provision and 1 participation (Lansdown, 2005). According to the CRC, states are obliged to protect children from all forms of discrimination and physical or mental violence: injury or abuse, neglect or negligent treatment, maltreatment or exploitation; economic exploitation or any work that may interfere with their education or is harmful to their health or physical, mental, spiritual, moral or social development; illicit use of narcotic drugs and psychotropic substances; all forms of exploitation that are harmful to any aspect of their welfare such as the abduction, sale of or traffic of children and all forms of sexual exploitation and abuse. At the same time, having in mind their vulnerability, the obligation of a state (adults) is to provide/ ensure children's survival and development: adequate family accommodation, health and social protection, adequate standard of living, compulsory and free primary education and options for secondary schooling; provision of appropriate and equal opportunities for cultural, artistic, recreational and leisure activity; the right to a name, family identity and citizenship, as well as legal and other assistance for defence purposes.

Protection and provision narratives are in harmony with the dominant image of the child as sensitive and vulnerable, in need of being protected from various sources of endangerment; also, the child who should be provided with all things necessary for survival and development. At the core of the protective and provision rights is a paternalistic attitude, i.e. the belief that in order for children to stay protected and supported they must be controlled and their choices limited. According to the 
protectionists, children need to be 'protected from themselves', i.e. from the possibility to making decisions and choices that might endanger their development (Archard, 2004). Adults' role is to be children's advocates and make decisions that are in the child's best interests. This role is justified by the image of the child as an immature, irresponsible, incompetent human being, a 'future adult' without competencies to make their own decisions that are in their best interest.

Some authors believe this discourse of vulnerability and risk is informed by developmental theories that stress children's lack of rationality, dependency and need for protection (Smith, 2016). Early developmental theories in psychology were strongly influenced by the romanticised discourse and Rousseau's ideas about natural development, which should not be fastened or conditioned in any way (Burman, 2008). The nativists in developmental psychology perceive development as a process determined in advance, which envelops a series of successive phases in predetermined order. Within this school of thought, the child is perceived as natural and predictable (Hogan, 2005). The natural child is universal, isolated, developed according to the natural developmental laws, universal and resistant to influences from the context; the child behaves according to predictable age parameters and laws (the predictable child). The process of a child's development to adulthood is advancing from simple to complex thinking, from irrational to rational behaviour. Socialisation is conceived as a one-way process, as the assimilation of the (natural) child into an already existing social environment/system. The path of the development is universal, while cultural differences are kind of 'embellishments' related to various socio-cultural practices (education, the ways of raising children, social norms etc.), rather than as something intertwined and immanent in the development (Burman, 2008). On the other side, the empiricists, with the behaviourists being the most influential among them, and later the social learning theorists, accepted the idea of John Locke about the child as a tabula rasa on which, during the life span, the experience imprints the traces. The empiricists conceive development as equal with the process of the acquiring experience and learning (the establishment of the relations between stimulus and reaction). Although confronted in terms of the importance they ascribe to the factors of the development (inheritance vs. environment), both naturalists and empiricists share the same image of the child and the contextual determination of the development. In both conceptions, the child is perceived as passive; the empiricist tradition is more explicit, being interested in the acquisition of experience, namely in the establishment of stimulus-response relations, neglecting the internal structures within a person. In that way, the child is a passive 
receiver of influences from the outside and the development could follow different paths, depending on positive or negative influences. The nativists, on another hand, insist on natural development, which is universal, predetermined and fixed, such that adults (and the child as well) have almost no space to intervene and influence the development. Yet another similarity is interesting, one related to contextual development. Within the nativist orientation, the role of the environment and social context of one's development is evidently neglected, while the empiricists stress its importance for the development, but only as a "better or worse framework, not as a source of child's development” (Matejić Đuričić, 20I2, p. 272). Such understanding of development has greatly influenced the image of the child which, according to sociologists, is dominant in western societies: childhood is just a period in human development, children are regarded as vulnerable developing beings deservedly surrounded by nourishment and care for protection; children are valued in terms of what they are to become as adults; they are seen as future adults rather than as beings of today (Christensen and Prout, 2005, p. 45).

\section{From vulnerability and risk discourse to oppressive practices}

The socially dominant image of the child/childhood hugely influences the attitudes to children and the way they are treated in a given society. That image suggests certain acceptable models of the adult-child relationship, the goals and the desirable forms of education and bringing up, and represents an important regime of truth (Foucault, 1977) or a system of social assumptions defining what could be accepted as truth, normality, the non-disputable fact, defining who can assess it and in which ways. As part of the regime of truth, the child's image becomes the basis (and justification) for various manifestations of oppressive practices with children since they are not disputed as normal social assumptions but accepted as such, as the only possible truth. These oppressive practices can sometimes be very evident and explicit (for example, denying children the right of expression of thoughts and freedom of association), and supported by explicit biases ('children are incapable of expressing their opinions'). Sometimes, those oppressive practices can become exposed through less evident, more subtle forms (for instance, adults do not inform children about things that matter to them) rationalised by attitudes that are expressed as protection and an attempt to do something in the best interest of the child ('they should not be overburdened with superfluous information and spoil their carefree childhood'). In that way, the image of the child becomes part of the regime of truth in society and a justification for various manifestations of oppression on both the individual and 
institutional levels. The image of the child as a vulnerable human being reduces the child to the object of adults' interventions and results in a denial of the child's competencies to participate in decision-making relevant to him/her, including his/her own protection and security (Boothby et al., 20I2; Kennedy, 2010).

The image of the child defines the relations of adults and children, too. According to some authors, the pattern of relations in societies where the child is defined as an emerging human being is one of protection, control and marginalisation (Qvortrup, 1998). A protective attitude stems from the idea of incompetence and irresponsibility of the child who has to be (over)protected. Control is reflected in the system of relations where the obedience and submission of children are encouraged, rather than their independence that is important for securing the developmental continuity between the role of child and of adult. Marginalisation is reflected in the child's invisibility, based on the assumption of their incapacity to articulate their perspective and/or express their opinion (observed as a rule, and different from the incompetence of the adult, which is assumed as an exception). It is thus assumed that the child's opinion is non-binding and that respect of the child's rights or meeting their needs is exclusively a matter of the care of adults.

Discrimination of children and adults' expectations of children substantially influence the way the children perceive themselves and their capacity to actively participate. The mechanism of self-fulfilling prophesy (Rosental and Jacobson, 1968) explains why children internalise the adults' image of themselves and demonstrate behaviour fully in line with that image. In other words, the image of the child as vulnerable really influences the resilience of children and decreases their resources to defend and resist various oppressive factors (Smith, 2016).

\section{Participative rights: Deconstruction of the oppressive practice}

One way of questioning an oppressive practice is to make its assumptions evident and explicit, to criticise and reconsider these assumptions and to then think about possible alternative opportunities for the (re)organisation of social relationships (Freire, 2005).

The socio-constructivist paradigm of the child's development contributed significantly to a different perception of the child, where they are no longer seen as immature, incompetent and passive. Within this paradigm, the child is observed as an active participant in the process of their own development, one who constructs/rationalises the surrounding world and the relationships within it. The child is a creator of meaning (Bruner and Haste, 1987) who, like a scientist, tends to actively conceive 
the surrounding world and is intrinsically motivated to learn (Piaget, 1952/1965). Instead of an isolated child who spontaneously and naturally learns new strategies and skills, the child is perceived as an 'apprentice' in learning: they actively learn by observing more experienced and more skilful peers/adults and develop new skills, which help them in resolving culturally defined problems. Found within the basis for development is the process of social interaction, i.e. the process in which the child works together with a more experienced person and resolves problems within the zone of proximal development, where participating in this way means their independent actions are surpassed (Vigotski, 1983). Guided participation includes the cooperation of the adults and children and the creation of common understanding during problem solution where the child participates as an active and the adult as a more skilful and more experienced partner (Rogoff, 1990).

The psycho-social approach among sociologists of childhood also adds significantly to the reconsideration of a biological, nativist approach to the development and the nature of the child. This approach accepts the immaturity of the child as given, but how this fact is interpreted depends on the historical epoch and variety among societies/cultures. The basis of the approach is the idea of social constructivism, whereby childhood is a matter of social convention and as such, changeable, depending on time and space. Sociologists of childhood observe the child as part of a culture, not only as something that precedes that culture. They assume that children should be seen as present social actors and not as somebody who will become a social actor. Children and childhood should be studied 'in their own right', independently of the adults' perspective and interests. Sociologists of childhood advocate the perception of the child that is not a project for the future, but a person who has capacities here and now; they advocate the study of children as individuals, not as an institution they form part of. If we define the child by comparing him/her with the adult, then we necessarily perceive the child as someone who has yet to become, not as somebody who is present here and now, with all competencies (those already developed as well as those that have yet to develop). Children should be viewed as active participants in the construction and definition of their own social life, the life of people surrounding them and the society in which they live (Praut and Džejms, 2004).

The idea of children as agents active in the process of their own development is advocated in the Convention on Child Rights through the idea of participation, conceived in three ways: a) as one of the four principles on which the CRC is based, together with non/discrimination, the best interest of a child and life, survival and development; b) as a group 
of participative rights, 'civil rights' (privacy, information, freedom of thought, conscience and religion, freedom of expression, right to receive and impart information and ideas, freedom of association and peaceful assembly); and c) as special Article 12 (the child has rights to express his/her views freely in all matters affecting him/her, the views of the child being given due weight in accordance with the age and maturity of the child).

Participatory rights assume the image of the child different from that offered by protection and provision rights: the child is no longer the object but becomes the subject of the rights, actively involved in realising these rights. The focus is on the child as an active human being permanently involved in the process of constructing their own social reality. Children are observed as autonomous personalities, subjects, participants in social processes, not as being passively owned by the adults, the objects of social control, and as social problems (Freeman, 1998). Children are perceived as individuals, not as a collectivity, a group without characteristics; which means that categories like age, gender, class, ethnicity, culture and others have an important role to play in understanding childhood. Observing the child's rights as those that were traditionally observed as adults' rights, and announcing participation as one of the four basic principles on which the CRC is based, means recognising the idea that childhood is a social phenomenon that children are active participants in public life and are capable of participating in the recognition of their own rights and the definition of their own best interest (James, 2009). The idea of the child as a subject of rights leads to a reconsideration of those beliefs which represent the firmest strongholds of the age-based discrimination against children known as adultism, usually seen as the abuse of the power that adults have over children (Flasher, 1978, according to: Liebel, 20I4). These beliefs are the following:

\section{The child is a project for the future, an emerging being}

This assumption builds on the idea of the incompetent, incomplete, immature child who is in the process of developing and thus incapable of any form of participation in the decision-making process. The assessment of the child's competencies for participation and adults' conclusion that children are not competent is frequently based o comparisons of the child's competencies with an 'ideal adult' who is always mature, rational, competent and autonomous. The list of adults' competencies makes high demands even on the adults, not to mention the child. Even when the competencies of a child are not compared with adult competencies, there is a tendency to assess them according to adult standards rather than according to what children really can do. The adults' standards and their 
expectations represent a framework in which adults perceive children and can significantly reduce adults' readiness to notice and value all of children's capacities and influence the ways children are treated and the opportunities created for them.

Janusz Korczak was among the first to advocate children's rights and to point out that children are entitled to the present moment: "Children are not people of tomorrow but of today. A child lives here and now. $\mathrm{He} /$ she has value as an individual in the present moment. When we think of a child as an embryo of a citizen, we lose sight of the important years of his/her here and now existence" (according to: Hammarberg, 2009, p. 8). In other words, participation requires the adults' assessment of the child's competencies to be related to what the child can do at the present moment rather than to what they would be able to do in the future. Age is not and cannot be an excuse for discrimination because every child is capable of expressing his/her views (perspective, needs, feelings etc.) according to his/her age and evolving capacities. Adults' role is to find the best communication channel through which children can express themselves. The basic question adults should ask while consulting children is not $D o$ they understand or not?, but What should we do to make them understand us? Would they understand us if they had more information, or if they were asked in a different way? (Alderson, 2000). The theory about the hundred languages of children (Malaguzzi, 1993) is a metaphor expressing the variety of ways children can express their opinions and ideas (such as painting, drawing, sculpturing, modelling, writing, dancing etc.). This explains why the usual communication practice of (written or spoken) language is insufficient if one intends to encompass and understand the complexity of the child's experience. As a result, adults are expected to explore new options for communication with children (beyond the conventional pattern where one person speaks and another listens), to learn new 'languages' for working with children, and new ways of listening to children's experiences (Moss, 2006).

If we observe a child as competent in the present moment, then they have no need to struggle to protect their own right to participate (as the protectionists say); instead, assumptions are made of the child's right to participate which can only be neglected when it is not in the best interest of the child or if it could endanger the right of another person. Liberationists assume that adults are obliged to justify with arguments any denial of the right to participate, rather than let a child 'struggle' for the right to participate in decisions relevant to him/her (Archard, 2004). 


\section{The child in need vs. the competent child}

The protection and provision discourse concentrates on the child's needs which are universal and do not depend on the socio-cultural context. This focus on needs conceals a danger that arises due to the assumption that adults are the only ones responsible for satisfying these needs, while children are simply passive receivers of adults' care and aid. The participation discourse includes the competencies which enable children to be active participants in their own development. The CRC guarantees the right of children to have their evolving capacities (competencies) respected, and according to age and maturity, to be gradually empowered to make decisions that affect them. Given that competencies do not emerge in a vacuum, but are defined by the culture and produced by the defined social structure, namely, they emerge and develop through relations of cooperation and within a social and cultural context, children develop their competencies by being active. In this way, participation not only depends on evolving capacities, but is also an important way of developing new, more complex competencies. Many studies show that children's participation fosters the development of competencies like critical-thinking and problem-solving skills (Hart, 1997; Lansdown, 2005; Kellett, 2005), self-regulation skills (Kellett, 2003), communication competencies, listening skills, skilful expression of attitudes, feelings and needs in an assertive way, conflict-resolution skills, team work, and cooperation (Hart, 1997). Moreover, such are the pro-social competencies: empathy for the feelings and needs of other people, responsibility and care for others, solidarity (Kellett, 2005; Lansdown 200I; 2005), self-esteem and positive self-image (Grover, 2005). Through the process of participation, children acquire knowledge, skills and values that prepare them for more complex forms of participation in adult life. From a developmental point of view, participation provides continuity between childhood and adulthood because it facilitates the development of the competencies required in every adult citizen in any democratic society.

The more children participate, the more effective their contributions and the greater the impact on their development. Children acquire competence in direct relationship with the possibility to exercise agency in their own lives (Lansdown, Jimerson and Shahroozi, 20I4).

\section{Adults are (better than children themselves) capable of estimating children's needs and their best interest}

The basis of such a view is the image of the omnipotent adult, an expert (having once also been a child) for the child's experience, and the image of the immature child incapable of assessing their own needs and expressing 
their own point of view. From socio-constructivists' perspective, this argument that children are passive recipients of environmental influences is untenable; rather, children actively learn and design the world around them in cooperation with adults. The age and competencies of children cannot be the argument for not listening to them, especially in the period of middle childhood and adolescence since this is the period when important competencies for complex forms of participation develop (Lansdown, 2005; Vranješević, 2004). However, despite the arguments in favour of children's competence to participate in defining their own best interest, the practice of avoiding consulting with children and one-sided adults' definition of what is the best for the child are still dominant characteristics of adults' attitude. The reason for this should be sought in the complex relationship between participation and the best interest of children because in the majority of cases the possibilities of the child's participation are not only limited by the assessment of child's (in)competence but by the adults' care for the child's benefits and protection from all possible negative consequences of particular choices. Some research shows that the most frequent reason given against child's participation in the decision-making process is related to the child's best interest, as perceived by the adults (Vranješević, 20I2), such that the basic question about the child's care is how to make an informed decision in the best interest of the child and simultaneously protect the child from the stress that is immanent to the decision-making process. Moreover, studies show that even if adults consider children as capable of assessing their best interest, they do not consider that competence as important (Vranješević, 2012). Typically, the practice used as a basis for resolving the dilemma between participation, the child's competence and the best interest of the child is problematic from the perspective of both the competence assessment and the child's best interest. If an adult believes that the child's decision is not in his/her best interest, the adult will most probably conclude that the child is incompetent, unable to decide. Therefore, whenever children use criteria decision different to the adults' criteria the adults assume that child's criteria are developmentally less valuable than theirs. In assessing the child's competence, adults are often in a dual role: it often happens that the same adults in charge of assessing the child's competence for participation are also in charge of deciding what would be the child's best interest, i.e. to what extent the child will participate in the decision-making process.

Since the standards for competence assessment are significantly higher in situations when the decisions could bring risky consequences, one may conclude that the same child could be assessed as competent in situations of low risk and incompetent in a situation of high risk. Keeping 
in mind that adults are those who decide what is a low and what is a high risk, the issue of competence is inseparable from the issue of adults' power and control over children. If it is a decision that will significantly influence other people (including the child as a future adult), the adult will more strongly influence and control the decision process and the child will be assessed as less competent.

There are two ways adults can induce the child's competence for decision-making: first, to teach children how to act, how to cope with environmental problems (how to participate actively); children could thereby become capable of doing some things while their decision competence grows; second, adults should control the environment in such a way that the decisions are less risky and reversible (Mortier, 1998). This would entail adults setting boundaries wide enough so that beyond them are only those behaviours/situations that directly jeopardise the physical and psychic integrity of the child, and within the boundaries the child can make their own free choices.

\section{Participation is not always in the best interest of children; protection must come before participation}

This argument justifies a more subtle form of discrimination, expressed as the protection of children and attempting to ensure their best interests; it rests on the belief that agency and dependency are opposite constructs. This 'either/or' thinking was challenged by Priscilla Alderson (200I) who sees the relationship between adults and children as 'both/and': both agency and dependency are important components of the relationship. Saying that children have agency does not imply they are completely autonomous in the decision-making process (and that adults do not have the right to say or do anything) or that protection and care are not important elements of the adult-child relationship.

If we perceive protection as a unique and key component of the adult-child relationship, we miss the chance to include children in the decision-making process about their best interest when it comes to securing and protecting their rights. Children's participation in the process of planning their safety and protecting their rights helps adults to de-centre and understand the children's priorities in different areas, and to acquire a more profound insight into the problems the children are coping with. All of this increases the chances that the decisions made are truly in the best interest of children. There are many examples of participatory projects and studies in which children actively participated (as experts in their own experience) in the process of protecting and realising their rights. For example, in studies on the problems of street children 
and child labour, the participation of those children was very important for understanding their views and in planning actions in their best interest (Vudhed, 2004; Young and Barrett, 2001; Theis, 1998). In one research study from Serbia, the consulting process with migrant children led to a more comprehensive understanding of their position and the problems they were coping with during the migration process, contributing thus to clearer definitions of the directions in which the advancement of the policies and programmes should take (Avramović, 20I4). There are numerous examples of projects/studies in which children were consulted about the ways their rights were respected (Hill, 2006; Lansdown, 2000; O’Kane, 2008; Pešić et al., 1999; Stevanović, 2012), which resulted in the advancement of policies for child protection and realisation of their rights which, in their opinion, were neglected. For example, in one study within the EURONET (European Children's Rights Network), the aim was to explore the experience of discrimination: whether children consider themselves as discriminated just because they are children, how such discrimination is accomplished, and with what effects. Children were consulted about the ways they would like to take part in the process of decision-making, not only on the local but the national and international level too. They had a chance to actively participate in formulating recommendations for the advancement of children's rights and their participation in the decision-making process (Lansdown, 2000). There are examples of initiatives which sought to create a safe and supporting context for the development and learning at schools, where the participation of students seriously advanced the quality of the research process and the research outcomes in the sense the decisions made advanced the protection and safety of children at schools. For instance, in one school in England, the 7-year-olds suggested research about peer violence and articulated the questions posed to their peers. Instead of focusing on the roles of perpetrator and victim (who does/suffers the violence), they concentrated on unsafe sites and asked their peers where the peer violence happens. As a result, the school intensified surveillance of the sites marked by the students as critical, thereby making these places safer (Rowe, 1999). This and other copious examples unequivocally show the potential children participation holds for the realisation of both participative and protective/ provision rights, and to erase the boundary (in adults' heads mostly impenetrable) between children's protection and their participation in the realisation of their rights. 


\section{Concluding remarks: Towards the deconstruction of adultism}

The concept of child rights acts as a call for the re-conceptualisation of the power relationships between children and adults because it focuses on the competent, active child, who is entitled to claim their rights (Tobin, 2011, p. 89). Instead of adult superheroes who satisfy children's needs by being good, considerate and humane, the rights-based approach highlights adults' obligation to provide all the support and protection during a child's development. Introducing participation as the main principle, child right and the group of civil rights, the CRC is contributing significantly to changing the regime of truth and to deconstructing the oppressive practices which are typically taken for granted.

The CRC brings a new perspective on the child's nature. Participation demands we adopt the image of the child as an active participant in the process of their own development. A child is no longer seen as a passive recipient of adults' influences, knowledge and experience but as somebody who, with his/her needs, interests and developmental competencies, participates in his/her environment and changes that environment. Some authors (Benedict, 1976) believe that, as the gap between the social interpretation of the child's and adults' role grows wider, it is ever more difficult to overcome the transition period from one role to another; hence, the period of adolescence carries the marks of turbulent crises and changes. If a child is seen as passive, immature, incompetent, irresponsible and dependent, the growing up that requires maturity, responsibility and independence will be denoted by crises and difficulties.

Participation redefines power relationships. Rather than the hierarchical model of power on which adultism is based, participation advocates a cooperative power model where power is shared and, instead of imposing the adults' opinion, there is a process of negotiation and dialogue with children.

The idea that children can and should be treated as experts in their own experience and as participants in the decision-making process completely transforms the habitual patterns of relationships among children and adults (Jones and Welch, 2010) and redefines the concept of the adult's authority and his/her role in protection and stimulation of child development. Instead of authority based on fear that values and develops a child's obedience and external locus of control, authority based on respect values and develops the child's independence, responsibility and critical attitude to reality. Such authority cultivates freedom of choice and self-discipline and develops the internal locus of control. Authority based on respect uses his/her power exclusively with the aim of protecting the 
child and when the best interest of the child is in question. Instead of control, authority based on respect controls the environment/conditions and acts preventively, organises the environment for development and learning, so as to prevent or lower the probability of unwanted forms of behaviour and to provide for the child's protection (Vranješević, 2005).

The fact that participation is a form of social learning makes it necessary to redefine the traditional roles of adults and children (Clark, 20IO). As participation promotes the image of the child as a creator of meaning, actively constructing and reconstructing their own experience and relations, and as the focus is on the co-construction of knowledge, participation creates options for new relationships and expands the role of both adults and children. Adults have the role of both teacher and student: they simultaneously support the child's development, encourage the child's competencies and learn during cooperation with the child (Rinaldi, 200I). Some authors label this role an authentic novice (Clark and Moss, 2005) because the adult gives up the privilege of knowing everything and is sincerely (authentically) interested in understanding and learning about the child's perspective.

In lieu of marginalisation, participation offers the visibility and emancipation of children as a social group, promoting the image of the child as an active partner in a social community whose voice is audible and respected. The practice of participation changes the status quo in power relationships by critically reassessing the following questions: Who usually speaks on behalf of the group? Who is allowed to speak and on whose behalf? (Cahill, Sultana and Pain, 2007). Participation holds transformative potential not only in relation to social change to which it can contribute but also in relation to the very participants, their competencies, attitudes and values. Through participation, children are stimulated to name the problems in their environment, to voice them, i.e. to speak about them, to explore them and, through the process of building allies (with adults), to influence the process of changes and to improve their own status in society (Vranješević, 20I5). Promoting the visibility of children's perspective is especially important when children come from marginalised groups (poor children, children with developmental difficulties, ethnic minorities etc.) since it is a way for improving their feeling of being powerful, their positive self-image, and their proactivity (Sime, 2008). Yet, these are not only relevant to children from marginalised groups (although they need additional support) but for all children because children/youth are generally a marginalised social group in terms of their visibility and social power. Participation gives children an option to be active participants whose opinion is asked for and respected, to learn how to think critically, 
to pose questions and interpret answers, and to actively contribute to improving the status of children. In this way, participation helps promote the image of children as active and competent experts in their own experience who, according to their age and evolving capacities, can participate in the decision-making process concerning their best interest.

\section{References}

Alderson, P. (2000) Young Children's Rights: Exploring Beliefs, Principles and Practice. London and New York: Jessica Kingsley publishers.

Alderson, P. (200I) Life and death: Agency and dependency in young children's health care. Children's Issues 5(I), pp. 23-27.

Archard, D. (2004) Children: Rights and childhood. London and New York: Routledge.

Avramović, M. (2014) Kad smo pitani, a ne ispitivani-konsultacije sa decom upokretu. Sarajevo: Save the Children International.

Benedict, R. (1976) Continuities and Discontinuities in Cultural Conditioning. In Skolnick, A. (ed.). Rethinking Childhood: Perspectives on Development and Society, pp. 19-29. Boston: Little, Brown and Company.

Boothby, N., Balster, R. L., Goldman, P., Wessells, M. G., Zeanah, C. H., Huebner, G., and Garbarino, J. (2012) Coordinated and evidence-based policy and practice for protecting children outside of family care. Child Abuse \& Neglect 36(10), 743-751.

Bruner, J. S., and Haste, H. (eds.). (1987) Making Sense: The Child Construction of the world. London: Methuen.

Burman, E. (2008) Deconstructing developmental psychology. London and New York: Routledge.

Cahill, C., Sultana, F., and Pain, R. (2007) Participatory ethics: Politics, practices, institutions. ACME: An International E-Journal for Critical Geographies 6(3), pp. 304-318.

Christensen, P., and Prout, J. (2005) Anthropological and sociological perspectives on the study of children. In Greene, S. and Hogan, D. (eds.). Researching children's experience. Approaches and methods, pp. 42-6r. London: Sage Publications.

Clark, A. (2010) Young children as protagonists and the role of participatory, visual methods in engaging multiple perspective. American Journal of Community Psychology 46(I-2), pp. II5-I23.

Clark, A., and Moss, P. (2005) Spaces to play: More listening to young children using the Mosaic approach. London: National Children's Bureau. 
Freeman, M. (1998) The sociology of childhood and children's rights. The International Journal of Children's Rights 6, pp. 433-444.

Freire, P. (2005) Pedagogy of the Oppressed. New York: The Continuum International Publishing Group, Inc.

Foucault, M. (1977) Discipline and Punish. London: Allen Lane.

Grover, S. (2005) Advocacy by children as a causal factor in promoting resilience. Childhood I2(4), pp. 525-538.

Hammarberg, T. (2009) Korczak - our teacher on the rights of the child. In Hammarnerg, T. (ed.). Janusz Korczak: The child right to respect, pp. 5 - II. France: Council of Europe.

Hart, R. A. (1997) Children's Participation - The Theory and Practice of Involving Young Citizens in Community Development and Environmental Care. New York: UNICEF.

Hill, M. (2006) Children's voices on ways of having a voice: Children's and young people's perspectives on methods used in research and consultation. Childhood $13(\mathrm{I})$, pp. 69-89.

Hogan, D. (2005) Researching the child in developmental psychology. In Greene, S., and Hogan, D. (eds.). Researching children's experience. Approaches and methods, pp. 22-42. London: Sage.

James, A. (2009) Agency. In Qvorturp, J., Corsaro, W. A., and Honig, M-S. (eds.). Childhood studies, pp. 34-45. New York, NY: Palgrave Macmillan.

Jones, P., and Welch, S. (2010) Rethinking children's rights: Attitudes in contemporary society. New Childhood Series. London, UK: Bloomsbury.

Kellett, M. (2003) Enhancing pupils' learning skills through their engagement with research process. Paper presented at Research in Practice Conference, Oxford: Westminster Institute of Education.

Kellett, M. (2005) Children as active researchers: a new research paradigm for the $2 I^{s t}$ century? UK: ESRC.

Kennedy, A. (2010) Children and the notion of risk: The nanny state? In Murphy, D. L., and Taylor, E. (eds.). Key Issues in Childhood and Youth Studies, pp. 75-85. Abingdon, Oxon: Routledge.

Lansdown, G. (2000) Challenging discrimination against children. Brussels: Euronet.

Lansdown, G. (200I) Promoting children's participation in democratic decision-making. Florence: Innocenti Research Center.

Lansdown, G. (2005) The Evolving capacities of the child. Florence: Innocenti Research Center. 
Lansdown, G., Jimerson, S. R., and Shahroozi, R. (2014) Children's rights and school psychology: Children's right to participation. Journal of School Psychology 52(I), pp. 3-12.

Liebel, M. (2014) Adultism and age-based discrimination against children. In Kutsar, D., and Warming, H. (eds.). Children and non-discrimination - Interdisciplinary textbook, pp. I19-I 44. Children's Rights Erasmus Academic Network (CREAN).

Malaguzzi, L. (1993) For an education based on relationships. Young Children (II), pp. 9-13.

Matejić Đuričić, Z. (2012) Nove konceptualizacije razvoja i vaspitanja. Specijalna edukacija i rehabilitacija (11)2, pp. 267-284.

Mortier, F. (1998) Rationality and competence to decide in children. In Verhellen, E. (ed.). Understanding children's rights - Ghent papers on children's rights, 3., pp. 79 - 100. Belgium: University of Ghent.

Moss, P. (2006) Listening to young children: beyond rights to ethics. In Davies, J. M. (ed.). Let's talk about listening to children: Towards a shared understanding for early years in Scotland, pp. 17-24. Learning and Teaching Scotland.

O'Kane, C. (2008) The development of participatory techniques: Facilitating children's views about decision which affects them. In Christensen, P., and James A. (eds.). Research with children: Perspectives and practices, pp. 125-156. New York and London: Routledge.

Pešić, M., Branković, B., Tomanović-Mihajlović, S., and Dejanović, V. (1999) Participacija mladih pod lupom. Beograd: Jugoslovenski centar za prava deteta.

Piaget, J. (1952/1965) The origins of intelligence in children. New York: International Universities Press, Inc.

Praut, A., and Džejms, A. (2004) Nova paradigma za sociologiju detinjstva? Poreklo, obećanja i problemi. In Tomanović, S. (ed.). Sociologija detinjstva, pp. 5I-77. Beograd: Zavod za udžbenike i nastavna sredstva.

Qvortrup, J. (1998) Sociological Perspectives on childhood. In Verhellen, E. (ed.). Understanding Children's Rights - Ghent Papers on Children's Rights, 3, pp. 125- 136). Belgium: University of Ghent.

Rinaldi, C. (200I) Documentation and assessment: What is the relationship? In Giudici, C., and Krechevsky, M. (eds.). Making learning visible, Children as individual and group learners, pp. 78-89. Cambridge, MA: Project Zero and Reggio Emilia: Reggio Children. 
Rogoff, B. (1990) Apprenticeship in thinking: Cognitive development in social context. New York: Oxford University Press.

Rosental, R., and Jacobson, L. (1968) Pygmalion in the classroom: Teacher expectations and pupils' intellectual development. New York: Holt, Rinehart and Winston.

Rowe, D. (1999) The business of school councils. London: The Citizenship Foundation.

Sime, D. (2008) Ethical and methodological issues in engaging young people living in poverty with participatory research methods. Children's Geographies 6(1), pp. 63-78.

Smith, A. B. (2016) Children's Rights: Towards Social Justice. New York: Momentum Press.

Stevanović, I. (2012) Izveśtaj o ostvarenosti prava deteta u Republici Srbiji iz ugla dece $i$ mladih. Beograd: Centar za prava deteta.

Theis, J. (1998) Participatory research on child labour in Vietnam. In Johnson, V., Ivan-Smith, E., Gordon, G., Pridmore, P., and Scott, P. (eds.). Stepping forward: Children and young people participation in the development process, pp. 8I-85. London: Intermediate Technology Publication.

Tobin, J. (20II) Understanding a human rights based approach to matters involving children: Conceptual foundations and strategic considerations. In Invernizzi, A., and Williams, J. (eds.). The human rights of children: From vision to implementation, pp. 6I-98. Farnham, UK: Ashgate.

Vigotski, L. (1983) Mišljenje i govor. Beograd: Nolit.

Vranješević, J. (2004) Participacija i razvoj u adolescenciji. Pedagogija 59(I), pp. $60-67$.

Vranješević, J. (2005) Participacija učenika i autoritet nastavnika. Inovacije u nastavi $\mathrm{I} 8(4)$, pp. 83-91.

Vranješević, J. (2012) Razvojne kompetencije i participacija dece: od stvarnog ka mogućem. Beograd: Učiteljski fakultet.

Vranješević, J. (2015) Od učesnika do istraživača: deca u participativnim istraživanjima. Beograd: Institut za pedagogiju i andragogiju Filozofskog fakulteta Univerziteta u Beogradu.

Vudhed, M. (2004) Borba protiv dečjeg rada: saslušajmo šta deca kažu. In Tomanović, S. (ed.). Sociologija detinjstva, pp. 316-345. Beograd: Zavod za udžbenike i nastavna sredstva.

Young, L., and Barrett, H. (200I) Adapting visual methods: Action research with Kampala street children. Area 33(2), pp. 141-152. 